\title{
DIGNITY
}

\section{Dignity: A Journal of Analysis of}

Exploitation and Violence

\section{"He Told Me that My Waist and Private Parts Have Been Ravaged by Demons:" Sexual Exploitation of Female Church Members by "Prophets" in Nigeria}

Chima Agazue

The University Centre, Blackpool and the Fylde College, chima.agazue@gmail.com

Follow this and additional works at: https://digitalcommons.uri.edu/dignity

Part of the Community Psychology Commons, Counseling Psychology Commons, Leadership Studies Commons, Social Psychology Commons, Social Work Commons, and the Sociology Commons

\section{Recommended Citation}

Agazue, Chima (2016) "'He Told Me that My Waist and Private Parts Have Been Ravaged by Demons:" Sexual Exploitation of Female Church Members by "Prophets" in Nigeria," Dignity: A Journal of Analysis of Exploitation and Violence: Vol. 1: Iss. 1, Article 10. https://doi.org/10.23860/dignity.2016.01.01.10

This Research and Scholarly Article is brought to you for free and open access by DigitalCommons@URI. It has been accepted for inclusion in Dignity: A Journal of Analysis of Exploitation and Violence by an authorized editor of DigitalCommons@URI. For more information, please contact digitalcommons-group@uri.edu. 


\title{
"He Told Me that My Waist and Private Parts Have Been Ravaged by Demons:" Sexual Exploitation of Female Church Members by "Prophets" in Nigeria
}

\author{
Abstract \\ In urban southern Nigeria there is a widespread spiritual revival pioneered by Pentecostal pastors who \\ claim to deliver prophecies, miracles, and healings. In many places, multiple churches can be seen within \\ a few hundred yards of each other, while in other places, different floors of multistory buildings are \\ occupied by different church denominations. There is competition among the pastors to present \\ themselves as spiritually powerful and financially favored by God. Some of the pastors, calling \\ themselves "prophets," engage in immoral and fraudulent activities. Women are the predominant \\ followers of these male religious leaders, and sexual exploitation of vulnerable women by these religious \\ leaders is common. The prophets sexually exploit vulnerable women with the promise of "spiritual \\ cleansing." Based on news reports, this article discusses cases of sexual abuse and exploitation of \\ women and girls by their pastors in Nigeria. These cases show how prophets promise that the sexual \\ interactions will enable the women to escape demonic possession or to fulfil the "will of God."
}

\section{Keywords}

Nigeria, religion, prophets, spiritual cleansing, exorcism, sexual exploitation, church women

\section{Creative Commons License}

\section{c) $($ ) $(9)$}

This work is licensed under a Creative Commons Attribution-Noncommercial-No Derivative Works 4.0 License.

\section{Acknowledgements}

This article is an expanded version of a conference paper entitled 'Spiritual Cleansing' through Private Parts: New Patterns of Sexual Exploitation of Female Church Members by their Revered 'Prophets' in Nigeria" which was presented at an Inter-Disciplinary Conference entitled Exploring Sexuality and Spirituality which took place in Oxford, United Kingdom from July 6-8, 2016. Two referees reviewed this article using a double-blind review process. Dignity wants to recognize the reviewers for their time and expertise. With the permission of the reviewers and the author, Dignity thanks Rev. Dr. Adobea Yaa Owusu, Senior Research Fellow and Senior Lecturer, Institute of Statistical, Social and Economic Research, University of Ghana, Legon and Accra Medical College, Accra, Ghana, and Dr. Ruth Van Dyke, Senior Lecturer in Social Policy, London South Bank University. 


\section{DIGNITY}

Volume 1, Issue 1, Article 10, 2016
A JOURNAL ON

SEXUAL EXPLOITATION

AND VIOLENCE

\title{
"HE TOLD ME MY WAIST AND PRIVATE PARTS HAVE BEEN RAVAGED BY DEMONS:" SEXUAL EXPLOITATION OF FEMALE CHURCH MEMBERS BY "PROPHETS" IN NIGERIA
}

\author{
Chima Agazue \\ The University Centre, Blackpool and the Fylde College
}

\begin{abstract}
In urban southern Nigeria there is a widespread spiritual revival pioneered by Pentecostal pastors who claim to deliver prophecies, miracles, and healings. In many places, multiple churches can be seen within a few hundred yards of each other, while in other places, different floors of multistory buildings are occupied by different church denominations. There is competition among the pastors to present themselves as spiritually powerful and financially favored by God. Some of the pastors, calling themselves "prophets," engage in immoral and fraudulent activities. Women are the predominant followers of these male religious leaders, and sexual exploitation of vulnerable women by these religious leaders is common. The prophets sexually exploit vulnerable women with the promise of "spiritual cleansing." Based on news reports, this article discusses cases of sexual abuse and exploitation of women and girls by their pastors in Nigeria. These cases show how prophets promise that the sexual interactions will enable the women to escape demonic possession or to fulfil the "will of God."
\end{abstract}

\section{KEYWORDS}

Nigeria, religion, prophets, spiritual cleansing, sexual exploitation, evil spirits, exorcism, church women

\footnotetext{
$\mathrm{S}$ EXUAL EXPLOITATION of vulnerable people is a global reality (Andrews, 2004; Willis and Levy, 2002; Flowers, 2001; Basak, 1991; Kelly et al., 1995). Factors contributing to forms of sexual exploitation have been well researched and documented. They include: poverty (Mikhail, 2002; Cluver et al., 2011; Lalor, 2004; Kiremire, 2006; Martens et al., 2003; Evans, 2010), unemployment (Martens et al., 2003), pedophilia (Campagna and Poffenberger, 1988), exposure to sexual exploitation or sexual abuse (Spangenberg, 2001; Nixon et al., 2002; Chase and Statham, 2005; Lalor, 2004; Dunlap et al., 2002), armed conflict or war (Martens et al., 2003; Hynes 2004; Min-Harris, 2010; Watts and Zimmerman, 2002), displacement (Ward and March, 2006), orphanhood (Cluver et al., 2011; Evans, 2010), a parent's or guardian's illness or death (Cluver et al., 2011), dysfunctional government (Min-Harris, 2010), globalization (Kelly and Regan, 2000; Danailova-Trainor and Belser, 2006), sex tourism (Ennew, 1986) and the legalization of prostitution in some countries (Bruinsma and Meershoek, 1997; Farley, 2009; Outshoorn, 2005). Women are also forced (Ruggiero, 1997; Kelly,
} 
2003; Hughes and Denisova, 2001) or tricked into sexual encounters without necessarily experiencing the aforementioned factors.

In Nigeria, a new form of sexual exploitation by church leaders, known as "prophets" has emerged. As noted by Agazue (2015), it is no longer news that some clerics sexually abuse some of the people in their care, but the news is how such abuse currently constitutes a major part of "exorcism." This article will demonstrate that unlike the well-known patterns of sexual exploitation of vulnerable church members by their leaders, the major precipitator in recent cases is the prophet's exploitation of the victims' fear of demons or evil spirits that are allegedly possessing them. It will show the role the so-called prophets play in convincing the female victims that the sex acts will save them from being possessed by an evil spirit or simply enable them to fulfil the "will of God." In current circumstances, church women's fear of demons or evil spirits or failing to fulfil the "will of God" and their faith and trust in the prophets cause them to deliver their bodies to their prophets to handle as they wish.

\section{Growth of Prophetic Churches in Nigeria}

Before exploring how managing prophetic churches is a money-making venture in Nigeria, it is worth stating that though prophetic churches and Christian prophets are ubiquitous in Nigeria, Islam and traditional African religions also can be found, including other minority religions in the country. The southern part of Nigeria is dominated by Christianity while the northern part is dominated by Islam (Agazue, 2013). Members of other minority religions, including the traditional African religions (which have now joined the minority following the growth and expansion of Christianity and Islam in the country) can all be found in both the southern and northern parts of the country.

Although the discussion on Christian prophets does not directly apply to these other religious groups, it is important to state that almost all the religions in Nigeria have their respective prophets who are equally active in their own styles. Members of these religions similarly seek divine revelations and take their leaders' words seriously, which has contributed to Nigeria becoming a spiritual world where many citizens continually talk about spirits or divine manifestations in both positive and negative terms (Agazue, 2015).

The activities of the prophets under discussion here are more common in the southern part of the country, where Christianity predominates. Agazue (2015) found that with the rate at which the residents of southern Nigeria patronize pastors, almost every street in the urban regions of southern Nigeria currently has a church. Since the region is experiencing widespread spiritual revival, the religiocommercial services offered by the pastors of prophetic and miracle-working churches grow stronger daily.

Obtaining statistical data that reflects the actual number of churches or at least provides a reliable estimate on the number of churches operating in Nigeria will be almost impossible because most self-styled pastors fail to register their churches with the relevant authority. Nigeria is known for corruption (Smith, 2007) and this has favored self-styled pastors or so-called prophets who establish their churches on their own and assign themselves any religious title (e.g., Prophet, Reverend, Pastor, Apostle, etc.) of their choice without following the due process required to obtain such titles (Agazue, 2015).

While obtaining an official record on the number of churches and pastors is difficult, both academic and media reports consistently report that the number of 
churches in the country and pastors have increased dramatically in recent times. For example, Smith (2007, p.212) claimed that the "number of prosperity churches is huge, with entrepreneurial pastors starting new churches seemingly every day." While this observation was made almost a decade ago, the situation has not changed as Agazue (2015) has recently validated. Standing at a bus stop on Okoya Street in Ajegunle, Lagos, Agazue (2015) was able to count six churches, with another six churches inside a compound along Cemetery Road in Amukoko, and a further 17 churches within a distance of approximately two miles along Old Ojo Road. He also published a photograph of half a dozen churches located inside a residential compound in Lagos and one of a two-story building housing five churches in Imo State.

It is, however, worth stating that the competition to establish churches on many streets is not driven by self-styled pastors alone-some registered and officially recognized churches in the country have long practiced this. In fact, it can be argued that the self-styled prophets model some of their styles on the activities of these officially recognized pastors. The general overseer of the Redeemed Christian Church of God (RCCG), Pastor Enoch Adeboye, for instance, ordained 8,151 deacons in August 2016 (Sahara Reporters, 2016). This same pastor also ordained 9,170 deacons in 2015 (Anjorin, 2015) and 8,622 in 2014 (Eyoboka and Latona, 2014). The above figures also include deaconesses. Such increased ordination provides an insight into the proliferation of prophetic and miracle-working churches in Nigeria and beyond. Other churches competing with RCCG also are increasing their clerics.

In his analysis of this ordination and some controversial sermons delivered by the general overseer of the RCCG, Pastor Adeboye, the Sahara TV presenter known as Dr Damages, jokingly said: "Most of these deacons will move on to become franchise owners" (Sahara Reporters, 2016). The presenter further added: "So you can as well give up hope that a street in your hometown will escape having a Redeemed Church on it. ... It is going to be like a Starbucks [coffee shops]" (Sahara Reporters, 2016). Similarly, an Al Jazeera journalist, Mohammed Adow, described the church as "as common as coffee shops" when televising an interview he had with Pastor Adeboye in Lagos in April 2013 (Al Jazeera, 2013).

Marshall (2015, p.9) observed that "a massive explosion of church planting," which means establishing more churches, has characterized charismatic and Pentecostal churches since the 1990s. She cites the presence of the RCCG in every nook and cranny of Lagos to illustrate this. The RCCG's general overseer, Pastor Adeboye, has repeatedly stated that RCCG will "plant" a church within a walking distance of five minutes in every urban Nigeria area, and within a driving distance of five minutes in the North American region (Marshall, 2015). As stated on one of its websites, the RCCG's "deliberate focus on church planting is tied to its organizational structure and the leadership of Adeboye" (RCCG, no date).

There are also other large and officially registered and recognized churches similar to the RCCG that also practice church "planting" although it isn't part of their organizational structure. RCCG illustrates the growth of prophetic churches in Nigeria, including overseas, for two important reasons: 1) RCCG is the largest Pentecostal denomination in Nigeria (Ukah, 2005); 2) RCCG in the Nigerian religious market has introduced trends that smaller churches have adopted (Ukah, 2005).

These churches compete with each other, and other denominations of Pentecostal churches, both popular and less popular, market their services widely and 
attract followers. Among the popular churches that compete with RCCG in church planting are the Living Faith Church Worldwide alias Winners Chapel and Believers Loveworld alias Christ Embassy. These three churches are the wealthiest Nigerian churches (The News Magazine, 2006, cited in Ukah, 2007a). While some of the pastors planting churches on the streets of Nigeria, including those "exporting" their churches abroad, may have honest intentions beyond material gains, the number of pastors delivering prophecies and receiving huge material rewards has geometrically increased (Agazue, 2015).

Pentecostalism has become both "the fastest growing industry in Nigeria and the second most popular export (after crude oil)" (Ukah, 2005; bracket in the original). Traditionally, a church is seen as a representative part of an institution whereby possessions (e.g., properties) belong to the church community and not to the pastor, but in Nigeria at present, many of the Pentecostal churches whose pastors compete to win followers are family-run businesses (Agazue, 2015). According to Ukah (2007b), pastors are the founder-owner of their churches, chief executive officer (CEO), consultant and financial authority. He also cites a common practice of giving the pastor's wife the highest post in the church hierarchy after her husband's position despite the presence of a Board of Trustees (BoTs). Ukah (2007b) refers to cases of deceased pastors in which their wives succeeded them as the CEO.

Agazue (2015) also observed that these pastors often claim their sons have a divine call and often ordain them as pastors and give them an important post in the church. These practices make these churches a family-run business. The founding pastor is the only person to appoint or dismiss an officer (Ukah, 2007b). Everyone is accountable to him/her but he/she is accountable to no one (Ukah, 2007b). Some churches that have succeeded in expanding nationwide (and in some cases, overseas) cannot be regarded as institutions of a religious nature because investigations (Ukah, 2005) have found that they operate on economic principles, with the majority of their significant profits going to their overseers or founders.

Nigerian Pentecostal churches use several techniques to make money through adherents, such as frequent crusades, vigils, anniversaries, conventions, prayer sessions, and exorcisms (Ukah, 2005). The churches also sell spiritual materials, such as olive oils, as well as souvenirs, such as magazines, books, stickers, pamphlets, key-holders, handkerchiefs, videos and audio discs/cassettes (Ukah, 2007b), T-shirts, and scarves (Agazue, 2015). The face of the pastor is often printed on clothing, which members believe is capable of providing them with miracles when needed, such as saving them from road accidents, armed robbery attacks, and other social ills (Agazue, 2015).

Agazue (2015) found that some of these materials are sometimes sold at more than 20 percent above their standard market prices to adherents who are convinced that their problems, such as sickness, impotency, poverty, and many more, will cease after purchasing and using these products. The religious activities described above (i.e., crusades, etc.) are designed to attract people and increase profits for the pastors (Ukah, 2005). Many older Christian denominations in Nigeria that felt threatened by the Pentecostal style of divine business have adjusted their style of business in order to retain members (Abioje, 2004; Ukah, 2005; Agazue, 2015).

Pastors who are relentless in marketing their churches use a variety of tools and techniques (Folarin, 2012; Agazue, 2015; Ukah, 2011; Houreld, 2009). Miracle advertisements in the media is one notable tool in this commercialization of religion (Ukah, 2011). These miracles are worth describing here since they often go 
hand in hand with prophecies. Often prophecies are made; for example, a pastor may tell a person: "The Lord has asked me to tell you that your demonic possession will be over as soon as you agree to meet his prophet." Then after meeting the prophet for exorcism, the person might feel that whatever had distressed or bothered him/her (i.e., the demonic possession) has ceased. The person is likely to be persuaded to give a testimony of how the Lord delivered him/her from demons through a particular prophet - an experience that is often described as a miracle.

The scores of pastors competing for members have resorted to miracle advertisements, which attract members (Ukah, 2011). Ukah (2011, p.49) argues that " $[t]$ he hub of the issue with the leaders of the Pentecostals, however, is that the competition for adherents, social visibility, and prestige is a strong factor in pastors using the media in displaying their 'credentials' and credibility." Media advertisements have become a trend and build fame by which pastors start making their money. The credibility of a particular pastor, according to Agazue (2015, p.175), is sometimes based on the number of miracles - albeit unverifiable miracles - displayed in the media.

Radio, newspapers, magazines billboards and posters are all actively used (Agazue, 2015). Often, pastors persuade or hire individuals to describe their alleged miraculous encounters. Such unverifiable claims of miracles are regularly published in front pages of popular newspapers and magazines in Nigeria, along with the name of a particular pastor, which may encourage those who feel they have a similar problem to meet the pastor.

\section{The Role of Prophets in Christendom}

The importance of prophecies and the role of prophets in Christendom can be found in several passages of the Bible. The Bible is replete with the works of dozens of prophets. Some of these prophets existed before the advent of Christ himself. They include: John the Baptist, Isaiah, Jeremiah, Daniel, Ezekiel and others. Both John the Baptist and Isaiah prophesied about the coming of Jesus Christ (Isaiah, 40:3; Mark, 1:1-3; John, 1:23), which was considered good news because of the redemption that Christians believe Jesus Christ brought to them. Prophets who prophesied about catastrophes also abound. Noah, for example, preached to his evil generation to repent but when they failed to heed him, God commanded him to build an ark to save his family and every kind of creature during the destruction by flood that would follow (Genesis, 6:13-22).

The Bible also describes "fake" prophets, who are said to prophesy from their imagination and follow their own spirit without any direction from God (Ezekiel, 13:2). The Lord did not send them and their divinations were rooted in falsehood (Ezekiel, 13:3). These latter prophets are more relevant to the analysis in this paper because of their similarities to the dubious characters of the present-day prophets.

The above Christian prophets were prophets of the past, whose deeds are documented in the Bible. However, many Christians believe prophets still live in their midst today in accordance with the biblical passages stating that God does not change his mind (1 Samuel, 15:29; Malachi, 3:6) in the way he does things. The importance of prophets is described in several passages of the Bible (Exodus, 4:16; Luke, 1:70), for instance making known the will and character of God, guiding people and warning them of an impending catastrophe resulting from sin.

Christians are admonished to "believe in God and his prophets in order to succeed" (2 Chronicles, 20:20). Studies suggest that Christians believe in biblical 
statements. For example, a Gallup survey in the United States found that 28 percent of participants believed that the Bible contains the actual word of God and 49 percent believe that it contains the inspired word of God (Newport, 2006). This suggests that any Christian who is determined to do the will of God will take the Biblical teachings seriously.

\section{Obsession with Prophecy in Nigeria}

It is common for members of the Nigerian Pentecostal churches to view their pastors as prophets. Unlike other Christian denominations who view their priests or pastors as playing the role of a church minister, divine or otherwise, increasingly members of the Nigerian Pentecostal churches believe that their pastors see God and/or hear from God (Agazue, 2015). One of the RCCG's websites states that the general overseer of the church, Pastor Enoch Adeboye, is "seen as a prophet and high priest" (RCCG, no date). This is not exceptional -- several other Pentecostal denominations competing with RCCG also regard their pastors as prophets.

Prophecies by popular Nigerian pastors are a major topic of discussion in public places, including criticisms by Nigerians who are often appalled by these socalled prophecies. It is common practice for these pastors to deliver prophecies for the New Year, and their congregants eagerly await such prophecies in order to guide them with their New Year's resolutions and plans. These prophecies often appear as headlines in major newspapers and magazines.

In addition to many pastors being viewed as prophets, Agazue (2015) observed that an increasing number of self-proclaimed pastors have chosen "prophet" as their title because of the reverence or idolization attached to it. He noted that millions of Nigerians go about on a daily basis seeking prophecies from these pastors, both ordained and self-styled, and this has contributed to the increase of revivalist churches managed by self-styled prophets.

The increased presence of these prophets and their ceaseless prophecies have contributed to a high level of superstition in the country. There is evidence to suggest that historically and cross-culturally, the rich and the poor, the educated and the uneducated are affected in any society where superstition reigns supreme, albeit to varying degrees. In Elizabethan and Victorian England when superstition was the norm, Rosen (1991, p.3) reports that both the learned and the ignorant relied on magic and the "miraculous interventions of the saints and devils" to explain any uncommon phenomena. Similarly, Notestein (2013, p.11) reports how superstition in Elizabethan and Stuart England "was a matter that concerned all classes from the royal household to the ignorant denizens of country villages."

However, other factors also come into play in Nigeria. For example, it has been consistently reported that religious participation and activities tend to be higher in societies experiencing economic hardship and political tension (Mbe, 2002; Ukah, 2011; Magbadelo, 2004; Agazue, 2015). These issues abound in Nigeria, including other social ills, such as insecurity and violence. These social ills prompt many citizens to seek divine protection, which the prophets often guarantee them. Further, the heightened competition and marketing described above have also contributed to the increase in prophecy and miracle-seeking in the country. In other words, "faith comes from hearing," according to a popular adage. Therefore, the more these prophets establish their churches on the streets, deliver prophecies and showcase miracles, the more citizens develop faith in them and demand prophecies and miracles. 
As prophets become ubiquitous, millions of prophecy and miracle seekers look for signs (i.e., prophetic ability and testimonies of miracles) to identify who is a legitimate prophet (Agazue, 2015). This has led to the pastors coming up with dubious prophecies and staged miracles to present themselves as legitimate. Financial exploitation in particular has become a major signature of these so-called prophets (e.g., see Essien, 2010; Ukah, 2011; Obiora, 1998), prompting many individuals who are desperate to get rich quick to establish a church and present themselves as a prophet (Agazue, 2015).

By examining the membership of many prophetic churches, Agazue (2015) found that significantly more women than men are particularly vulnerable to the prophets' services. This is partly because of cultural expectations shaped by the patriarchal nature of the society. For instance, "[w]omen are expected to be productive in childbearing, otherwise the whole bargain of marriage in Nigeria would be considered a loss and a "bad market" (Essien, 2010, p.653). However, giving birth is not an automatic solution to the problem--a woman with up to six children can still be seen as a "bad market" in the absence of a male child. Such expectations have led many women to seek the prophecies and miracles guaranteed by these socalled prophets who use the women to make a lot of money (Agazue, 2015).

The approach of menopause is another factor identified by Agazue (2015), who found unmarried women being financially and sexually exploited by their prophets as they desperately sought a husband while still able to conceive. Increasing number of pastors have established their ministries with unmarried women in mind. These pastors use a variety of methods, including unverifiable testimonies of miracles and prophecies alleged to have come true, to give the women searching for life partners the impression that they are spiritually chained, hence, can only attract their life partners by consulting the prophets who are capable of breaking the so-called spiritual chain (Agazue, 2015).

Although these pastors also target men looking for wives, women face double jeopardy for three major reasons:

- The biological clock previously mentioned puts women under intense pressure to get married as soon as possible.

- The culture that prohibits childbearing outside marriage or single parenting affects women more than men. This makes women more desperate for marriage because they may not want to bear the shame associated with childbearing outside marriage or single parenting. If a man impregnates a woman outside marriage, the woman bears greater consequences than the man. For example, the woman is the one to carry the pregnancy and bring up the child with her resources and in her own home while the man may remain almost invisible. While some people may see the man as irresponsible, the woman is seen not only as irresponsible but also as a "whore."

- The culture prohibits a woman from making the first move in marriage. This means that unlike a man who is culturally expected to approach a woman to ask her to marry him, a woman often waits for the man to do so as widely expected. For a bold woman who is capable of approaching a man to make a marriage request, the culture still works against her because even if the man accepted, the woman is culturally not allowed to start the processes (e.g. marriage proposal, calling for a meeting of the kindred, paying a dowry, etc.) in a situation where the man is hesitant to do so. 


\section{Sexual Exploitation by Nigerian Prophets}

Agazue (2015, pp.16-17) has previously described how many prophets have emerged in Nigeria "whose exorcism methods include 'anointing' the genitalia (private parts) of women whom they allege are possessed by witchcraft, mermaids or marine spirits." One incident in Nigeria occurred in Lagos as reported by a local newspaper:

The victim, 24-year-old Cynthia Nwanguma, said she was placed on a secrecy oath by a Lagos based self-styled prophet, Dennis Mmadu, not to disclose her ordeal to anyone or else she would die.

Thereafter, Mmadu had free sex with her for seven days; pretending to be anointing her breasts and private part with oil. She added that the prophet also claimed he was having holy sex with her while he engaged in unprotected sex with her whenever he feels like throughout the period (Adeniran, 2012, no page number).

This alleged spiritual transaction with the victim, a student nurse, was designed to heal her from a strange illness that the prophet told her she had. The prophet also convinced her that the strange illness would make her barren all her life. The prophet showed her photos of men and women who had purportedly benefited from his spiritual works before charging her $\$ 21,800$ (approximately $£ 60$ ), which is a huge sum of money for a student. When the victim regained her rationality, she requested her money back but was ignored by the prophet. Police were eventually called and the prophet was arrested.

The second case happened between a 37-year-old pastor and his 18-year-old female church member in Kogi State. The following took place between the two individuals based on an interview with the victim named Mary:

He told me that my waist and private parts have been ravaged by demons and until deliverance was carried out, I may not be able to have any child. "The Man of God" frightened me and said he would only cast out the demons from me through sexual intercourse but he warned me not to tell anybody on the mode of deliverance.

After praying into an olive oil, he asked me to undress while he rubsed [sic] my waist and private parts with the anointing oil mixed with some substances, he then undressed himself and used the same oil on his private part before he descended on me and started to do the thing. ... (Nigerian Eye, 2014).

The victim later became pregnant and it was at that point that her parents became aware of this activity and then reported it to the police, who arrested the pastor. The pastor however, denied engaging in sexual intercourse with the woman, but accepted that he did cast out demons with an olive oil.

A third case occurred in Ekiti State in October 2014, when a 29-year-old selfproclaimed pastor had sex with a 19-year-old woman, after convincing her she would receive a spiritual cleansing from him, according to information provided to journalists by the police's public relations officer, Victor Babayemi, based on the pastor's confession (Gbenga, 2014). Like the first case above, the victim felt unhappy afterward and told police, who eventually arrested the pastor. 
In all the above cases the women took their pastors' purported prophecies seriously. They complied due to their fear of the evil spirit or demon alleged to possess them. The involvement of police in these cases is evidence the women would not have wanted to engage in such activities, although it was one victim's parents who alerted the police in her case.

It was possible that the victim herself was unable to report her experience to the police. This is common in such cases. Agazue (2015), for instance, found during his investigation that many pastors' victims still live in fear of the unknown after victimization, hence, would never disclose their ordeal and choose to die in silence instead. Further, intimidation by dubious pastors, their high status in the society and their access to some powerful personalities, including law enforcement agents and those in the legal profession, all increase their victims' subjugation.

Besides adults, it is also worth discussing how fear of possession by demons or evil spirits promotes sexual molestation and rape of minors in Nigeria. Children are increasingly being sexually abused by pastors through grooming, after developing a rapport with the child's family. The African culture of collectivism and interdependence (Owusu-Bempah and Howitt, 2000; Agazue, 2015; Wessells, 2008) and social cohesion inadvertently promotes such grooming.

In November 2015, the Nasarawa State Police command arrested 46-year-old Pastor Ifeanyi Bernard for raping a 13-year-old girl during an exorcism session. The pastor's arrest, according to the Commissioner of Police, Sani Mohammed, followed a report by the victim's father (Vanguard News, 2015). According to the pastor: "I have been a friend of the family for quite some time" (Vanguard News, 2015). The pastor also explained that he "met this young girl through her father" (Vanguard News, 2015). He acknowledged: "I used my anointing oil [i.e., a symbol of exorcism in this situation] to lure her into my room. ..." (Vanguard News, 2015). Before raping the girl, the pastor, according to the investigating officer, "threatened to kill the victim if she reported the incident to any member of her family" (Vanguard News, 2015).

Traditionally, molestation and rape of children by priests or pastors result from the presence of children in the church compounds or the pastor's residence, such as children serving as altar boys or girls and of course, the cleric developing a rapport with the child's parent or guardian. In Nigeria, parents leave their children with their pastors in order to give the pastor enough time to exorcise the child believed to be possessed or already labeled possessed. An example is the case of an 11-year-old girl raped by a pastor in Onitsha, the commercial hub of Anambra State in June 2012. The mother of the girl suspected her child of being possessed by an evil spirit and took her to a pastor for exorcism - a suspicion confirmed by the pastor who then asked the frightened woman to leave her daughter with him overnight for a "perfect" exorcism. This so-called perfect exorcism ended up with the pastor raping the girl three times.

As noted by Agazue (2015), suspicion of children being possessed by demons, a witchcraft spirit, or other supposed mischievous spirits is commonplace due to pastors' repeated preaching or prophecies on how children could be possessed. In some areas (most especially Akwa Ibom and Cross River states), such beliefs have led to the torture and murder of scores of children, as documented by Houreld (2009) and Agazue and Gavin (2014). Agazue's (2015) recent investigation, however, discovered that most of the children labeled possessed were experiencing psychological disorders, or copying what they observed from adults, particularly 
through the mass media or social media, including gifted children whose exceptional skills and talents infuriate their parents and prophets.

The pastors' descriptions of supposed psychological disorders or aberrant behaviors in children as signs of evil spirit possession have led to frightened parents taking their children to their pastors to be examined. Pastors are often quick to confirm parents' suspicion due to financial gains to be made from exorcism, including fame, sexual satisfaction, and other benefits. On the other hand, there are pastors who, without expecting the aforementioned benefits, confirm parents' suspicions or even come up with their own findings due to a genuine belief in evil spirit possession and possibly poor knowledge of what constitutes psychological disorders or the sources of aberrant behaviors (Agazue, 2015).

The last sexual encounters involving pastors and their followers to be discussed here are those promoted by women's desperation to do "the will of God." These cases differ from the above cases in that the women were happy with the prophecies, lived with the pastor for a considerable period of time, accepted being impregnated by him, gave birth for him and, in some cases, even introduced their daughters to the pastor for the same purpose. Hence, it remains debatable whether these cases can adequately be described as "exploitation."

A 53-year-old self-styled pastor, Timothy Ugwu, who once served as a scrutiny officer and statistician with the National Bureau of Statistics in Enugu, told police that he had five wives and 13 children, in addition to concubines who did not live with him in his Vineyard Ministry Church compound, Enugu (Vanguard News, 2014). These women had all been married but were persuaded to leave their husbands by the pastor, who described his act as "in line with the directives of the Holy Spirit to do the will of God, which is an act of spirituality" (Vanguard News, 2014). The church thrived on secrecy--the compound was barricaded with a heavy metal gate, which was always locked in order to prevent outsiders from observing the pastor's activities. The women and the children inside were almost entirely cut off from the world.

These cases appear to be different from the patterns of sexual abuse committed by religious leaders in the sense that the victims were motivated by fear of spirits or demons or the need to fulfil the "will of God." They may have believed that these men who demanded sexual intercourse with them were true prophets of God and must have heard directly from God, who suggested such encounters for a good cause. The victims agreed to cleansing of their private parts, which eventually led to sexual intercourse. Those married by pastors believed that leaving their husbands to remarry the pastor was a spiritual exercise and agreed to it.

This latter case raises some important questions: First, Christianity does not encourage polygamy, raising the question of how such a practice can be claimed as godly. Second, divorcing one's partner as the self-styled pastor's new wives divorced or separated from their husbands is not in keeping with Christian practice and again raises questions on how God can be pleased with it.

Christians are admonished to "believe in God and his prophets in order to succeed" (2 Chronicles, 20:20), as previously discussed. One may argue that the fear of not doing what a prophet has suggested may be preventing some adherents from being more rational. However, one needs to look beyond the belief itself to consider the personality and circumstances of the victims of these abuses. More research is needed into the influence of such factors. 
The above cases should raise the suspicions of any observer that "[t]his seems strange, it must be a scam," as van Eck Dymaer van Twist (2014, p.53) would say after observing credulous practices by certain religious minorities. It also raises the question: "Why would people [victims] engage in such acts in the name of God?" The following thought-provoking question by Shupe (2008) may provide some insights: "Could not one person's experience of alleged stifling control [by an authoritarian clergy] be another's spiritual growth-enhancing discipline?” (ibid., p. 23, bracket by me). The answer may be that among followers of dubious pastors, understanding is subjective. As observed by Agazue (2015), while some victims of sexual abuse and financial scams by their pastors in Nigeria accept their position as the will of God, others are angry. Ironically those who become angry are attacked by many church members who accuse them of not having faith or of seeing with a carnal eye as opposed to seeing with a spiritual eye.

\section{CONCLUSION}

This article has explored cases of sexual abuse of female church members by prophets who claimed to be carrying out God's instructions. It has demonstrated a pattern of sexual abuse and exploitation by individuals in a position of trust. Some victims were preyed upon particularly because of their fear of evil spirits or demons alleged to possess them. Others were convinced that their sexual experiences were designed to fulfil the "will of God." The article has also highlighted a form of grooming of minors whose parents trust prophets or are acquainted with prophets. This article is a wake-up call for female church members who believe that their pastors cannot be wrong especially when the pastors make unbelievable requests. While it may be difficult to convince such individuals to stop accepting prophecies from their pastors, they are advised to become more rational in heeding their prophets' claims. Church women should become better enlightened on the potential causes of their problems, including those of their children. Gaining such knowledge can help them to become more critical of prophets who label them possessed and suggest the sexual-style of exorcisms described in this article.

\section{ACKNOWLEGMENTS}

This article is an expanded version of a conference paper entitled "'Spiritual Cleansing' though Private Parts: New Patterns of Sexual Exploitation of Female Church Members by their Revered 'Prophets' in Nigeria," which was presented at an Inter-Disciplinary Conference entitled Exploring Sexuality and Spirituality, which took place in Oxford, United Kingdom from July 6-8, 2016.

Two referees reviewed this article using a double-blind review process. Dignity wants to recognize the reviewers for their time and expertise. With the permission of the reviewers and the author, Dignity thanks Rev. Dr. Adobea Yaa Owusu, Senior Research Fellow and

Senior Lecturer, Institute of Statistical, Social and Economic Research, University of Ghana, Legon and Accra Medical College, Accra, Ghana, and Dr. Ruth Van Dyke, Senior Lecturer in Social Policy, London South Bank University. 


\section{AUTHOR BIOGRAPHY}

Chima Agazue, M.Sc., is a lecturer in Criminology and Criminal Justice at the University Centre, Blackpool and Fylde College, UK. He earned a B.Sc. (Hons) in psychology and criminology at the University of Huddersfield. He is a British-Nigerian citizen with research interests in sub-Saharan Africa. He focuses on religiously motivated deviance, sexual exploitation, fraud, violence and homicide. He is particularly interested in violence and homicide motivated by the belief in witchcraft, human sacrifice and evil spirit possession. $\mathrm{He}$ plans to complete his $\mathrm{PhD}$ in forensic and criminal psychology at the University of Huddersfield in the near future. Email: chima.agazue@gmail.com

\section{RECOMMENDED CITATION}

Agazue, Chima. (2016). "He told me my waist and private parts have been ravaged by demons:" Sexual exploitation of female church members by "prophets" in Nigeria. Dignity: A Journal of Sexual Exploitation and Violence. Vol. 1, Issue 1, Article 10. DOI:10.23860/dignity.2016.01.01.10. Available at http://digitalcommons.uri.edu/dignity/vol1/iss1/10.

\section{REFERENCES}

Abioje, Pius. "A theological discourse on the Pentecostal emphasis on miracles in Nigeria." Nigerian Journal of Humanities 11 (2004).

Adeniran, Bisola. "Lagos Prophet turns Woman to Sex Slave, pretends to 'anoint' her Breasts and Private Part.” Daily Post, 14 August 2012. Viewed on 3 June 2016. http://dailypost.ng/2012/08/14/lagos-prophet-turns-woman-sex-slavepretends-anoint-breasts-private-part/.

Agazue, Chima. "Psychological Impacts of Animism and Religiosity on the Igbo People of Nigeria." MSc by Research Thesis submitted to the University of Huddersfield"s Research Office, 31 July, 2013.

Agazue, Chima. The Role of a Culture of Superstition in the Proliferation of ReligioCommercial Pastors in Nigeria. Bloomington: AuthorHouse, 2015.

Agazue, Chima and Gavin, Helen. "Evil and Superstition in Sub-Saharan Africa: Religious Infanticide and Filicide." Paper presented at the $6^{\text {th }}$ Global Conference on Evil, Women and the Feminine Conference, Lisbon, May 2 2014. Viewed on 2 June 2016.

https://www.researchgate.net/publication/262486738_Evil_and_Superstition in Sub-Saharan Africa Religious Infanticide and Filicide.

Al Jazeera. "Miracles promised at Massive Nigeria Church.” 13 April 2013, Viewed on 3 October 2016. https://www.youtube.com/watch?v=Cyjr2B5B8r8.

Andrews, Sara K. "U.S. Domestic Prosecution of the American International Sex Tourist: Efforts to protect Children from Sexual Exploitation." The Journal of Criminal Law and Criminology 94 (2004): 415-454.

Anjorin, Femi. "RCCG retires 20 Senior Pastors, ordains 9170 Deacons." PM News, 3 August 2015. Viewed on 1 October 2016. http://www.pmnewsnigeria.com/2015/08/03/rccg-retires-20-senior-pastorsordains-9170-deacons/.

Basak, Amima. "Child Prostitution Worldwide." International Criminal Police Review 428 (1991): 6-17. 
Bruinsma, Gerben J.N. and Meershoek, Guus. "Organised Crime and Trafficking in Women from Eastern Europe in the Netherlands." Transnational Organised Crime 3 (1997): 105-118.

Campagna, D.S. and Poffenberger, D.L. "Sexual Trafficking in Children: An Investigation of the Child Sex Trade." Office of Justice Programs, 1998. Viewed on 2 June 2016. https://www.ncjrs.gov/App/Publications/abstract.aspx?ID=107798.

Chase, Elaine and Statham, June. "Commercial and Sexual Exploitation of Children and Young People in the UK: A Review.” Child Abuse Review 14 (2005): 4-25.

Cluver, L., Orkin, M., Boyes, M., Gardner, F. and Meinck, F. “Transactional Sex amongst AIDS-Orphaned and AIDS-affected Adolescents predicted by Abuse and extreme Poverty." Journal of Acquired Immune Deficiency Syndromes 58 (2011): 336343.

Danailova-Trainor, Gergana and Belser, Patrick. Globalization and the Illicit Market for Human Trafficking: An empirical Analysis of Supply and Demand: Working Paper No. 78. Geneva: International Labour Office, 2006.

Dunlap, Eloise, Golub, Andrew, Johnson, Bruce D. and Wesley, Damaris. "Intergenerational Transmission of Conduct Norms for Drugs, Sexual Exploitation and Violence: A Case Study." British Journal of Criminology 42 (2002): 1-20.

Ennew, Judith. The Sexual Exploitation of Children. New York: St Martin's Press, 1986.

Essien, Anthonia M. "Proliferation of Churches: A Leeway to Commercialisation of Religion.” European Journal of Scientific Research 45 (2010): 649-657.

Evans, Ruth. "Poverty, HIV, and Barriers to Education: Street Children's Experiences in Tanzania." Gender and Development 10 (2010): 51-62.

Eyoboka, Sam and Latona, Olayinka. "RCCG opens Convention with Ordination of 8,622 deacons." Vanguard, 4 August 2014. Viewed on 8 October 2016. http://www.vanguardngr.com/2014/08/rccg-opens-convention-ordination8622-deacons/.

Farley, Melissa. "Theory versus Reality: Commentary on Four Articles about Trafficking for Prostitution.” Women's Studies International Forum, 32 (2009): 311-315.

Flowers, R. Barri. “The Sex Trade Industry's Worldwide Exploitation of Children.” The ANNALS of the American Academy of Political and Social Science 575 (2001): 147-157.

Folarin, George O. "How Valid are the Emerging Responses from Three Selected Pentecostal Churches in Nigeria to Poverty?” Cyberjournal for PentecostalCharismatic Research, 2012. Viewed on 1 June 2016. http://www.pctii.org/cyberj/cyberj21/Folarin.html.

Gbenga Ariyibi, "Police arrest "Pastor" for Rape.” Vanguard, 11 October 2014. Viewed on 1 June 2016. http://www.vanguardngr.com/2014/10/police-arrest-pastor-rape/.

Houreld, Katharine. "African children denounced as 'witches' by Christian pastors." Huftingpost.com, 18 October 2009. Viewed on 4 February 2016. http://www.huffingtonpost.com/2009/10/18/africanchildrendenounce n 324943.html.

Hughes, Donna M. \& Denisova, Tatyana A. "The Transnational Political Criminal Nexus of Trafficking in Women from Ukraine." Trends in Organised Crime 6 (2001): 43-67.

Hynes, H. Patricia. “On the Battlefield of Women's Bodies: An Overview of the Harm of War to Women.” Women's Studies International Forum 27 (2004): 431-445.

Kelly, Liz. "The Wrong Debate: Reflections on Why Force is Not the Key Issue with Respect to Trafficking in Women for Sexual Exploitation." Feminist Review 73 (2003): 139-144. 
Kelly, Liz and Regan, Linda. Stopping Traffic: Exploring the Extent of, and Responses to, Trafficking in Women for Sexual Exploitation in the UK: Police Research Series, Paper 125. London: Home Office, 2000.

Kelly, Liz, Wingfield, Rachel, Burton, Shelia and Regan, Linda. Splintered Lives: Sexual Exploitation of Children in the Context of Children's Rights and Child Protection. Ilford: Barnado's, 1995.

Kent, Stephen A. "Religious Justifications for Child Sexual Abuse in Cults and Alternative Religions." International Journal of Cultic Studies 3 (2012): 49-74.

Kiremire, Merab Kambamu. "Gendered Poverty Breeds Trafficking for Sexual Exploitation Purposes in Zambia.” Agenda: Empowering Women for Gender Equity 20 (2006): 18-27.

Lalor, K. “Child Sexual Abuse in Tanzania and Kenya." Child Abuse \& Neglect 28 (2004): 833-844.

Magbadelo, John Olushola. "Pentecostalism in Nigeria: Exploiting or Edifying the Masses?” African Sociological Review 8 (2004): 15-29.

Marshall, Ruth. "Dealing with the Prince over Lagos": Pentecostal Arts of Citizenship. EDGS Working Paper 22, 22 January 2015. Viewed on 3 October 2016. http://www.edgs.northwestern.edu/wp-content/uploads/2015 101/Marshall WP.pdf.

Martens, Jonathan, Pieczkowski, Maciej Mac and van Vuuren-Smyth, Bernadette. "Seduction, Sale and Slavery: Trafficking in Women and Children for Sexual Exploitation in Southern Africa." International Organisation for Migration (IOM) Regional Office for Southern Africa, May 2003. Viewed on 1 June 2016. http://www.unhcr.org/4d523c689.pdf.

Mbe, Akoko Robert. "New Pentecostalism in the Wake of the Economic Crisis in Cameroon.” Nordic Journal of African Studies 11 (2002): 359-376.

Mikhail, Susanne Louis B. "Child Marriage and Child Prostitution: Two Forms of Sexual Exploitation." Gender and Development 10 (2002): 43-49.

Min-Harris, Charlotte. "Youth Migration and Poverty in Sub-Saharan Africa: Empowering the Rural Youth." Tropical Review Digest: Human Rights in SubSaharan Africa, 2010. Viewed on 1 June 2016, http://www.du.edu/korbel/hrhw/researchdigest/africa/YouthMigration.pdf.

Newport, Frank. “Twenty-Eight Percent believe Bible is Actual Word of God.” Gallup, 22 May 2006. Viewed on 1 June 2016. http://www.gallup.com/poll/22885/twentyeight-percent-believe-bible-actualword-god.aspx.

Nigerian Eye. "Pastor impregnates Teenage Girl undergoing Spiritual Deliverance." 23 January 2014. Viewed on 1 June 2016. http://www.nigerianeye.com/2014/01/pastor-impregnates-teenage-girl.html.

Nixon, Kendra, Tutty, Leslie, Downe, Pamela, Gorkoff, Kelly and Ursel, Jane. "The Everyday Occurrence: Violence in the Lives of Girls exploited through Prostitution.” Violence Against Women 8 (2002): 1016-1043.

Notestein, Wallace. A History of Witchcraft in England from 1558 to 1718. England: The Floating Press, 2013.

Olukoya, Sam. "Nigerians divided by TV Miracle Ban." $B B C, 8$ June. Viewed on 3 October 2016.

http://newsvote.bbc.co.uk/mpapps/pagetools/print/news.bbc.co.uk/2/hi/africa 33784659.stm.

Outshoorn, Joyce. (2005). "The Political Debates on Prostitution and Trafficking of Women.” Social Politics 12 (2005): 141-155. 
Owusu-Bempah, Kwame and Howitt, Dennis, Psychology beyond Western Perspectives. Leicester: British Psychological Society, 2000.

Obiora, Fidelis K. The Divine Deceit: Business in Religion. Enugu: Optimal Publishers, 1998.

RCCG. "Redeemed Christian Church of God is rapidly planting devout congregations." No date. Viewed on 1 June 2016. http://rccgna.org/About-Us/The-Church/RCCGIn-The-News/ArticleID/58/Redeemed-Christian-Church-of-God-is-rapidlyplanting-devout-congregations.

Rosen, Barbara. Witcheraft in England: 1558-1681. USA: The University of Massachusetts Press, 1991 originally published in 1969.

Ruggiero, Vincenzo. "Trafficking in Human Beings: Slaves in Contemporary Europe.” International Journal of the Sociology of Law 25 (1997): 231-244.

Sahara Reporters. "Dr Damages Ep 242: Buhari wins Olympic Gold Medal.” 9 August 2016. Viewed on 1 June 2016. https://www.youtube.com/watch?v=z0CZGbN_wxI\&feature=youtu.be.

Shupe, Anson. Rogue Clerics: The Social Problem of Clergy Deviance. New Brunswick \& London: Transaction Publishers, 2008.

Smith, Daniel Jordan. A Culture of Corruption: Everyday Deception and Popular Discontent in Nigeria. New Jersey: Princeton University Press, 2007.

Spangenberg, Mia. "Prostituted Youth in New York City: An Overview.” Office of Justice Programs, March 2001. Viewed on 1 June 2016. https://www.ncjrs.gov/App/abstractdb/AbstractDBDetails.aspx?id=198146.

Ukah, Asonzeh F. K. "Globalisation of Pentecostalism in Africa: Evidence from the Redeemed Christian Church of God.” IFRA Ibadan Special Research 1 (2005): 93-112.

Ukah, Asonzeh. "African Christianities: Features, Promises and Problems." Institut für Ethnologie und Afrikastudien, Johannes Gutenberg-Universität. Working Paper 79 (2007a).

Ukah, Asonzeh. "Piety and Profit: Accounting for Money in West African Pentecostalism." Part 2. Nederduitse Gereformeerde Teologiese Tydskrif 48 (2007b).

Ukah, Asonzeh. "Banishing Miracles: Politics and Policies of Religious Broadcasting in Nigeria." Politics \& Religion, 5 (2011): 39-60.

Van Eck Dymaer van Twist, Amanda. "Minority Religions and Fraud: In Good Faith.” In Bona Fide, edited by Amanda Van Eck Dymaer van Twist. United States: Ashgate Publishing, 2014.

Vanguard News. "God directs me to impregnate married women and their daughters Pastor.” 26 July 2014. Viewed on 1 June 2016. http://www.vanguardngr.com/2014/07/sacrilege-pastor-impregnates-marriedwomen-daughters-says-god-directs/.

Vanguard News. "Pastor rapes 13-year-old during deliverance, says it's devil's work." 10 November 2015. Viewed on 8 October 2016. http://www.vanguardngr.com/2015/11/pastor-rapes-13-yr-old-duringdeliverance-says-its-devils-work/.

Ward, Jeanne and March, Mendy. "Sexual Violence against Women and Girls in War and its Aftermath: Realities, Responses, and Required Resources." Paper presented at the Sexual Violence in Conflict and Beyond Conference, 21-23 June 2006, Brussels. Viewed on 2 June 2016. http://www.operationspaix.net/DATA/DOCUMENT/1045 V $\sim$ Sexual Violence Against Women and Girls in War and Its Aftermath Realities Respon ses and Required Resources.pdf. 
Watts, Charlotte and Zimmerman, Cathy. "Violence against Women: Global Scope and Magnitude.” The Lancet 359 (2002): 1232-1237.

Wessells, Mike. "Trauma, Peacebuilding and Development: An African Region Perspective." Paper presented at the Trauma, Development and Peacebuilding Conference in New Delhi, India, September 9-11, 2008. Viewed on 8 September 2016. http://www.incore.ulst.ac.uk/pdfs/IDRCwessels.pdf.

Willis, B.M. and Levy, B.S. "Child Prostitution: Global Health Burden, Research Needs, and Interventions.” The Lancet 359 (2002): 1417-1422. 